\title{
Staging Roman History, Stuart Politics, and the Duke of Buckingham: The Example of The Emperor's Favourite
}

Court favourites and the dangerous effects of royal favouritism were popular subjects with Renaissance authors and they became newly topical in England following the 1603 accession of James I. Even before he became king of England, James Stuart was known for favouring young handsome courtiers, and it was not long before he began to display this taste within the English court. During the early part of his reign James's recognized favourite was Robert Carr, earl of Somerset (1585/6-1645), but a series of disputes with the king and Carr's trial for the murder of Sir Thomas Overbury in 1616 saw him lose his place as favourite to George Villiers (1592-1628), later duke of Buckingham. Like Somerset before him, Villiers was rewarded with multiple honours and came to exercise considerable power at court. His influence, however, was to prove more controversial and longer-lived, outlasting James's reign. Despite occasional friction between them during James's lifetime, Charles I and Buckingham became close allies, and Buckingham retained his position as influential court favourite up until the moment of his assassination on 23 August $1628 .{ }^{1}$ Buckingham had his admirers and allies, but most contemporaries were anxious about his influence over the Stuart kings. Indeed, many came to believe that he was responsible for leading both James and Charles astray in the 1620 s.

Early Stuart literature reflects these concerns and the broader contemporary anxiety about the potential influence of royal favourites that Buckingham's career fostered. The 1620s and 1630s saw a series of publications about favouritism and infamous historical favourites such as Sejanus — including Pierre Matthieu's The Powerfull Favourite, Or, the Life of Aelius Sejanus in two translations (1628) and Giovanni Battista Manzini's Politicall Observations upon the Fall of Sejanus, translated by Sir Thomas Hawkins (1634) - and dealing with infamous English favourites - for example Francis Hubert's Historie of Edward the Second (1628; reprinted 1629). ${ }^{2}$ There appears to have 
been a similar vogue for plays featuring, or about, royal favourites in the early Stuart era. According to Mario DiGangi, the Index of Characters in Early Modern English Drama 'lists forty-five printed plays from the sixteenth and seventeenth centuries in which characters identified as "Favourite(s)" appear', most of which 'come from the Caroline period'.'

Buckingham was a source of even greater contemporary interest, inspiring a large body of contemporary poems and texts, many of them libellous. ${ }^{4}$ Andrew McRae argues that manuscript miscellanies from the 1620s reveal that 'debate on Buckingham was the single dominant issue in the nation' and Curtis Perry argues that 'the discourse of corrupt favouritism' was 'the period's most important unofficial vehicle for exploring constitutional unease concerning the nature and limits of personal monarchy within the balanced English constitution.' 5

In recent years historians and literary critics have shown growing interest in the literature of early modern favouritism and the poetry specifically inspired by, and for, Buckingham. At least one relevant contemporary text has received comparatively little attention, however, probably because it is preserved in only one manuscript of which we know: ${ }^{6}$ The Emperor's Favourite is an anonymous seventeenth-century Roman tragedy bound together with three other manuscript dramas and additional early modern materials in a volume in the library of the Newdigate family of Arbury Hall, Nuneaton (MS A414). ${ }^{7}$ Probably written in the late 1620 s or early 1630 s, and based on the playwright's reading of classical authors such as Juvenal, Suetonius, and Tacitus, The Emperor's Favourite dramatizes the tragic rise and fall of Crispinus, the corrupt favourite of the tyrannical Roman Emperor Nero (37 CE-68 CE). ${ }^{8}$ A subplot focuses on the battle for the Armenian throne between Tiridates (brother of Vologesus, king of Parthia) and Tigranes (Nero's deputy in Armenia). ${ }^{9}$ A series of sustained contemporary parallels and allusions, however, makes it clear that the play combines Roman imperial history and fiction to offer an oblique critique of the career of the duke of Buckingham and the Stuart court, thus tapping into topical anxieties about Buckingham's influence as well as the effects of royal favouritism more generally.

\section{Roman History and Stuart Politics}

In using Roman history to 'touch the $\mathrm{p}^{\mathrm{r}}$ sent times' (5.2.3592), the anonymous author of The Emperor's Favourite follows the example of other Stuart dramatists. The early seventeenth century saw something of a vogue for 
plays about the history of the Caesars and imperial Rome, most of which are covertly concerned with topical issues such as court corruption, the nature and limits of royal power, and the rights and duties of subjects. ${ }^{10}$ Renaissance readers and theatre-goers were accustomed to thinking analogically, and it was common to interpret history in terms of its relation to, and its lessons for, the present. ${ }^{11}$ The English thus read Roman history in the light of present Renaissance events. In fact, Annabel Patterson argues that there was 'a massive exploitation of Roman history as a context for interpreting contemporary events' in the seventeenth century, not least because of the perceived parallels between the rule of the Caesars and the increasingly absolutist states of Europe. ${ }^{12}$ As Patterson notes, Roman writers provided a precedent for the topical interpretation of the past, too, for the 'the concept of oblique political comment was itself a Roman tradition, its strategy explained in Quintilian's Institutes. ${ }^{3}$ Thomas Heywood suggests in his defence of plays that dramatists were accustomed to using the past in this way, claiming 'If wee present a forreigne History, the subiect is so intended, that in the liues of Romans, Grecians, or others, either the vertues of our Country-men are extolled, or their vices reproued'. 14

The strategy of offering oblique commentary on the present through the representation of the past was partly dictated by the wish to avoid censorship and punishment. At this time, government policies forbade playwrights from commenting directly on contemporary political issues and individuals. Individuals who were publically critical of the king or his ministers faced being sent to the Tower, as was Sir John Eliot after his outspoken criticism of Buckingham in the 1626 parliament. ${ }^{15}$ There was potentially more scope for direct political commentary and satire when writing in manuscript, but it was not without its risks, as demonstrated by the high profile pursuit of some of the alleged authors of popular manuscript libels. ${ }^{16}$ It is perhaps not surprising, therefore, that the Newdigate playwright, like the professional playwrights of London, preferred to offer his commentary on Buckingham and Charles through the medium of Roman history. At the same time, in using Roman history as a mirror for Stuart England, contemporary playwrights, like the Newdigate dramatist, were also partly responding to the royal family's own appropriation of imperial iconography. ${ }^{17}$ While James and Charles generally invited comparisons with the more benign and successful Roman emperors, the possibility of drawing parallels with other emperors such as Nero had been suggested by at least one writer patronized by the court: Edmund Bolton (1574/5-c1634). In his Nero Caesar, Or Monarchie 
Depraued (1624), which he had submitted to the king before publication and had dedicated to the duke of Buckingham, Bolton likens Nero to a monarch and uses his example to argue that monarchical rule is preferable to other forms of government, even when headed by a tyrant like Nero: 'if Nero ... could not putrifie those strengths which princedome gaue more vnto the state, then either the commons, or the nobles when they ruled all, who can enough admire, or reuerence that sacred institution which virtue crownes, and vice cannot dissolue. ${ }^{18}$ It was an argument calculated to appeal to James I who was interested in Nero and 'fond of alluding to Paul's advice to the primitive Christians enjoining their allegiance to the tyrant who persecuted them (Romans 13:1-7, also 12:14)'.19 Bolton also challenged the arguments made by contemporary political theorists such as James's one-time tutor, George Buchanan (1506-1582), that subjects had a right to depose rulers who acted tyrannically. ${ }^{20}$ Nonetheless, in describing Nero as a monarch, Bolton made him available as a figure for contemporary kings, including the Stuarts in England.

\section{John Newdigate III}

The probable owner and author of the Arbury plays is John Newdigate III (1600-1642), son of Warwickshire magistrate John Newdigate II (15711610) and his wife Anne (née Fitton) (1574-1618). With his tastes for drama, poetry, art collecting, and horse-racing and an active interest in contemporary politics, John Newdigate III is, as Newdigate family historian Vivienne Larminie notes, 'an apparently obscure, but perhaps not untypical, member of the Caroline elite.'. ${ }^{21}$ The Emperor's Favourite thus offers a 'rare' and potentially valuable 'insight' both into early seventeenth-century manuscript culture and the political and cultural interests of the 'Caroline elite' beyond early Stuart London. ${ }^{22}$

Newdigate was classically educated and briefly attended Oxford University, where his reading appears to have included Suetonius, Juvenal, and Tacitus, the main sources for The Emperor's Favourite. ${ }^{23}$ Letters later sent to Newdigate by his Oxford-based friend Gilbert Sheldon (1597-1677) show that the Warwickshire landowner was familiar, too, with contemporary political allegory and the new mode of 'politic' historical writing, influenced by Tacitus, that emerged in the Renaissance. Sheldon promised to pass on information on 'the interpretation of such proper names' as occur in John Barclay's Latin political romance Argenis (1621) on 6 May 1622, and he sent 
Newdigate a copy of Sir Francis Bacon's History of Henry VII on 30 July $1622 .{ }^{24}$

Like many members of the gentry, Newdigate kept up to date with current affairs throughout the late Jacobean and Caroline eras, as well. The other materials found in Arbury ms A414 are indicative in this respect. They include a number of topical Jacobean texts, inferably collected by Newdigate or his brother Richard (1602-78), such as a 'proiect for A newe dignitie, betweene Barrons \& knights' (f 24), a paper 'vpon the present estates of Germanie and Bohemia' from 1620 (ff 26-34), and a contemporary copy of the 'Apologetic Petition of the Commons' to King James (6 December 1621) (ff 13-14v) submitted following the king's displeasure with the 'Petition and Remonstrance of the Commons Against Popery — the Spanish Match'. ${ }^{25}$ Other family papers include similarly topical material, such as a newsletter about the dissolution of the 1626 parliament following the attempted impeachment of Buckingham and two copies of Thomas Scott's infamously anti-Spanish Vox Populi (1620). ${ }^{26}$

Like their contemporaries, the Newdigates appear to have had a specific interest in Buckingham and the subject of royal favourites. The family's papers include a number of Buckingham-related texts from the 1620s, such as a copy of the king's speech made following the dissolution of the controversial 1628 parliament (14 April 1629), which presented a remonstrance against the royal favourite, and Newdigate's detailed, three-volume diary recording many of the speeches made during this parliamentary session, in which he sat as MP for Liverpool. ${ }^{27}$ As the editors of Newdigate's diary note, his 'is the most complete of all the known private diaries' relating to the 1628 parliament, and the document suggests that Newdigate was 'interested especially in keeping a record, either for his own personal satisfaction or for future reference, of what was being said and done in the House of Commons', recognizing 'the importance of this parliament for his own time and the future. ${ }^{28}$ With such detailed notes to hand and an insider's awareness of the criticisms Buckingham faced, Newdigate was well placed either to write or judge a play touching the duke's career.

Vivienne Larminie's identification of Bodleian Library Eng. poet Ms e.112 as Newdigate's manuscript commonplace book affords further evidence of an interest in favourites. It includes an epitaph 'On $S^{r}$ Walter Rawleigh', 'that antithesis of the fawning effeminate favourite', and notes on Hubert's controversial Historie of Edward the Second (1628), which deals with the tragedy of Edward and the downfall of Gaveston and Spenser, royal favourites 
to whom Buckingham had been likened. ${ }^{29}$ Evidence of a special interest in Buckingham is, likewise, suggested by a letter Newdigate received from Gilbert Sheldon in which Sheldon alludes to the arrest of Dr Alexander Gill in September 1628; Gill reputedly toasted John Felton, Buckingham's assassin, and said 'that our king was fitter to stand in a Cheapside shop, with an apron before him and say "What lack ye?" than to govern a kingdom. ${ }^{30}$

The association of the Newdigates with a manuscript copy of a popular anti-Buckingham ballad alluded to in The Emperor's Favourite offers further potential proof of their interest in the favourite and of their connection to the play. In the opening scene of act 5 , Datus talks of acting 'the cleane contrary way' (5.1.3017). The same words featured as a refrain in an anti-Buckingham ballad known to be circulating in the late spring and early summer of 1627.31 Such was the popularity of the ballad that 'for some it became Buckingham's signature song. 32

The incorporation of a contemporary manuscript copy of Richard Corbett's 'To ye duke of Buckingham' (1623) in Arbury Ms A414 provides more direct evidence of the family's interest in the favourite's career (ff 71-2). Corbett, who was a supporter of Buckingham and a beneficiary of his patronage, praises the duke and is specifically supportive of his close relationships with King James and his son (f 72, 11 80-2). Like other members of the Stuart gentry, the Newdigates were keen to collect texts that offered contrasting, even 'diametrically opposed', perspectives on the contemporary political scene and leading figures within it, such as Buckingham. ${ }^{33}$

\section{Buckingham, Crispinus, and Court Favouritism}

As well as including anachronistic allusions to English Renaissance court life and making the story of a favourite the centre of his play, the Newdigate playwright explicitly addresses the subject of court favourites. Court player and satirist Datus describes the 'diuers seruices' or functions of court favourites (1.1.349). This includes noting that

sometimes they are

Imployd to cross $\mathrm{y}^{\mathrm{e}}$ people, $\&$ to sway

All things against their bent

while other 'wise kings' (369) 'interpose' them ''be='twixt them \& y censure / Of meaner men' (370-1). Datus's satirical survey of favourites and their functions follows Nero's introduction in the play's opening scene of 
the 'meanely clothed' Crispinus (73) as the man he means to promote as his favourite. Historically Crispinus is reputed to have been a slave freed and advanced 'for his vices sake by Domitian Caesar to be Master of his Horse'. This office may have suggested the parallel with Buckingham, who was master of the horse at the Stuart court from 4 January 1616 and is famously depicted in terms of his equestrian prowess in Peter Paul Rubens's Equestrian Portrait of the Duke of Buckingham (c1625) (see Plate 1). ${ }^{34}$ But the Newdigate playwright's characterization of him as favourite is inspired more specifically by Crispinus's part in Juvenal's first and fourth Satires, where he is castigated for his profligacy and crimes including incest and the deflowering of a nun. ${ }^{35}$ No other English writer appears to have likened Buckingham to Crispinus. An extended series of parallels makes it clear, however, that Juvenal's lesserknown Roman favourite is a figure of, and for, the powerful English duke, mirroring the contemporary parallels drawn between Buckingham and Sejanus, classical history's most infamous favourite. ${ }^{36}$

Like Buckingham, Crispinus rises to power from relatively modest country origins, having been sent to court by his mother (2.1.645) in his 'country weeds' (1.1.410). Buckingham's origins were not mean but they were modest and rural. He was the second son of Sir George Villiers, a member of the Leicestershire gentry, and his wife Mary (née Beaumont). The playwright's inclusion of a dialect word associated with Leicestershire in the dialogue of Crispinus's brother, Hillarius - 'snept' (2.1.800, 801, 890), meaning 'to speak sharply, rebuke; to interrupt with scolding, to snap' - may be a nod towards Buckingham's Leicestershire origins, and it suggests the Newdigates' familiarity with the dialect of their neighbouring county. ${ }^{37}$

Just as Buckingham's success at court was partly attributed to his handsome looks, so Crispinus's 'dayntie shape' (4.1.2120) and well-proportioned limbs appear to recommend him within Nero's Rome. In his ability to assume a humble, loyal, and dutiful persona and in his ability to charm the emperor, Crispinus also displays a talent for dissimulation and manipulation of the kind frequently attributed to Buckingham. Crispinus shares some of Buckingham's passions, too, including a taste for fine horses. As master of the horse for James I and Charles I, Buckingham was responsible for importing Spanish, Italian, Arabian, and Barbary horses, and he became a well-known horse-breeder and racer, as Newdigate, a fellow horse enthusiast, knew well. ${ }^{38}$ Many of the same horse breeds are found in Crispinus's stable, its stock reportedly including 'Neopolitan coursers', 'nimble footed Barbaries', 'swift Arabians', and 'spirited Turkes' (4.1.2063, 2066-7). Like 
Buckingham, Crispinus is also reported to have a passion for the collection of curiosities, which he is said to store in a 'cabinet of raryties' (3.1.1155). Many noblemen collected art and antiquities in the period: Buckingham was one of the most famous, employing a number of agents to find and procure fine art and rare artefacts for him, including Balthasar Gerbier, who specifically praised the duke in 1625 for 'the treasure of rarities which your excellency has in so short time amassed', and Daniel Nys, a Dutch merchant, who alluded to 'His excellency's cabinet'. ${ }^{39}$

Crispinus's eventual assassination resembles that of Buckingham as well. ${ }^{40}$ The duke was stabbed and killed on 23 August 1628 by John Felton (c1595-1628), a disillusioned soldier who had served under Buckingham in the failed Île de Rhé mission (1627) and to whom Buckingham reputedly owed pay. Felton claimed that the idea of murdering the duke came to him after reading the parliamentary remonstrance prepared that year against Buckingham. He believed that 'by ... killing the Duke he should do his country great service. ${ }^{41}$ Crispinus is assassinated by Tigranes, the deposed ruler of Armenia, who also believes that he acts for the good of the state. When Tigranes stabs Crispinus, he claims to 'take the comon wealths reuenge' (5.3.3778) and to have 'quit the world of its disturber / And made the empire quiet' (3784-5). ${ }^{42}$

The play's topical allusions are not confined to the character of Crispinus. Crispinus's family members and followers, most of whom are the playwright's inventions or adaptations of material from classical sources, also appear to be partly based on relations and associates of Buckingham. Thus, although Crispinus's ambitious mother Locusta borrows her name from the woman reputedly employed by Nero as a poisoner, her characterization suggests that she is a parody of Buckingham's mother, Lady Compton, later countess of Buckingham (c1570-1632). ${ }^{43}$ Like the latter woman, Locusta ruthlessly exploits her son's influence to advance her family. ${ }^{44}$ Similarly Locusta's foolish husband, whom we never see, but whom Pronus disparagingly describes as a man whose

$$
\begin{aligned}
& \text { 'face is set } \mathrm{w}^{\text {th }} \text { rubies' } \\
& \text { A very puffe a thing } \ldots . \text { ' }^{\mathrm{t}} \text { takes' Tobacco } \\
& \mathrm{w}^{\text {th }} \text { as much confidence as a porter in a gallery } \\
& \text { In the new play house } \quad(3.2 .1263-6)
\end{aligned}
$$

appears to allude to the countess of Buckingham's third husband, Sir Thomas Compton. By the countess's own account Compton liked to drink and smoke 
rather more than was good for him. Writing to Buckingham in 1623 about his stepfather's illness, she remarks that 'Dr. Hunton hath given him physic, but hath done him little good; his opinion is that his excess of tobacco and wine hath hurt his brain'. ${ }^{45}$

Crispinus's sister Theodora and her husband Cesonius Petus potentially invite similar comparison with Buckingham's sister Susan Villiers (1591?1655) and her husband-turned-naval commander William Fielding, earl of Denbigh (c1587-1643). ${ }^{46}$ Petus, who is loosely based on one of the figures described in Tacitus's history of Nero, bungles the campaign to regain the Armenian throne, having received his command as a consequence of the favourite's backing and despite being deemed unfit by at least one experienced soldier 'to take this burden on him' (3.5.1980). ${ }^{47}$ In much the same way Denbigh enjoyed a series of naval appointments in the 1620s thanks to Buckingham's patronage but enjoyed little success and faced condemnation for incompetence: he was part of the failed military expeditions to Cadiz (1625) and the Île de Rhé (1627), and he led the unsuccessful naval mission to relieve the besieged Huguenots of La Rochelle (1628). ${ }^{48}$ At least one contemporary blamed the failure of the latter mission on Denbigh's poor leadership. Shortly after the fiasco, Sir Ferdinando Gorges wrote to Buckingham that there was 'no such difficulty in the relief of that place as it seems was pretended', adding, 'He that shall enterprise businesses of this nature must be a captain capable of the affairs, both by sea and land, and one whose spirit and judgement must sway without fear in the greatest distress. ${ }^{49}$ By implication Denbigh, like Cesonius Petus, did not measure up to this standard.

Hillarius, Crispinus's foolish older brother, and his wife Aurelia do not feature in any of the play's sources but appear to be partly modelled on Buckingham's elder brother John Villiers, viscount Purbeck (1591?-1658), who was prone to periodic fits of madness, and his wife Lady Frances Coke (1599-1645), who was presented before the Court of High Commission in 1625 after allegedly committing adultery and mothering an illegitimate child with her reputed lover Sir Robert Howard. ${ }^{50}$ Crispinus lays a similar charge of adultery at the door of the pregnant Aurelia, suggesting anachronistically that she too should be brought before the High Commission for her alleged crime against her eccentric, simpleton husband $(5.1 .3329 ; 3364) .{ }^{51}$

Two of the characters patronized by Crispinus likewise appear to find part of their inspiration in contemporary individuals. Pronus, the quack 'Doctor'-cum-bawd who becomes one of Crispinus's servants and claims to have 'a little / skill i'th' black art' (3.2.1286-7), appears to be a parody of 
contemporary astrologer and alleged 'witch' Dr John Lambe (1545/6-1628). Lambe's contemporary John Chamberlain (1553-1628) condemned him as 'a notorious rascal', presumably because Lambe was accused of sorcery in 1623 and convicted of rape in 1624, although he was later pardoned for the latter on 23 June $1624 .{ }^{52}$ Locusta appears to allude to Lambe's royal pardon when recommending the 'Doctor' to her son, claiming that 'the poore rascall had like to haue bene / hang' d' had she not intervened on his behalf with Nero (1290-1). At least some contemporaries believed that Buckingham had intervened in like manner to secure Lambe's pardon. ${ }^{53}$

Buckingham consulted Lambe on a number of occasions and the 'doctor' became popularly known as the 'Duke's wizard'. ${ }^{54}$ Lambe's association with Buckingham and people's perception of him as 'a transgressive figure perceived to have breached common boundaries of religious and sexual decorum' appear to have played a part in Lambe's violent murder by a London mob on his way home from the Fortune Theatre on Friday, 13 June 1628.55 In a pioneering essay about Lambe's death and its significance, Alastair Bellany argues that contemporary 'evidence suggests that the London boys and apprentices' responsible for the attack 'were acting out on the decrepit body of John Lambe their violent impulses towards the all-too-vigorous body of George Villiers', and 'attacking a constellation of profound moral and politically resonant disorders and inversions that both he and the victim Lambe were perceived to embody'. ${ }^{56}$ It was presumably no coincidence that the attack on Lambe happened at a time when parliament was preparing its remonstrance against Buckingham. Bellany suggests that the debating of parliament's grievances against the duke, 'encapsulated in the parliamentary remonstrance' against him, 'supplied the immediate parliamentary context, and perhaps the immediate trigger, for the assault on Lambe. 57

Datus, the court actor and playwright who finds himself in trouble with Nero after performing a speech castigating the emperor's crimes, derives his name and role from Suetonius's account of the emperor's life but appears to be partly based on another well-known contemporary, Ben Jonson. Jonson had been the court's main masque writer during the Jacobean period and was a renowned satirist, occasionally finding himself on the wrong side of the authorities as a result. He was questioned for his part in writing the controversial plays The Isle of Dogs (1597) and Sejanus (printed 1605) and for his alleged composition of a verse libel celebrating the assassination of Buckingham, 'To his Confined Friend Mr. Felton' (1628). (Jonson claimed that the latter poem was written by his friend, Zouch Townley, who fled 
to the Hague. ${ }^{58}$ ) As well as sharing with Jonson a taste for satire and an implicit desire to educate the court and its ruler through his art, Datus is disappointed in his quest to become master of the revels, as was the playwright at the Jacobean court, complaining at the start of act 5

Now may I goe hang my selfe, $\wedge^{\top} I$ haue' flatter'dthe em= perour seuen yeare together to get the master oth' reuells place, $\&$ now the blind iade furtune ... kicks, \& threatens me to be a stage keeper againe $(5.1 .2937-40)^{59}$

The fact that Crispinus intercedes with Nero on Datus's behalf and that Datus consequently praises the favourite (3462-4) may glance, likewise, at the fact that Buckingham was Jonson's patron on at least one occasion, despite the playwright's reputedly ambivalent views of the duke. Buckingham commissioned The Masque of Gypsies from Jonson for performance before King James at Villiers's Rutland home, Burley-on-the-Hill (3 August 1621). ${ }^{60}$

\section{Power and Abuse}

Arguably more significant than the apparent parallels between Crispinus's circle and Buckingham's family and associates are the implicit similarities between the uses Crispinus and Buckingham make of their court promotions and power. Buckingham was to become infamous for his engrossing of royal patronage and court offices as well as for his elevation of his kin. ${ }^{61}$ In 1616 the royal favourite became baron Whaddon and viscount Villiers; he was later made earl of Buckingham (1617), marquis (1618), and finally duke of Buckingham (1623). The last title was an especially great honour, for, as Roger Lockyer notes, he was 'the first duke for nearly a century to have no royal blood in his veins'. ${ }^{62}$ The only other dukes in Stuart England were Prince Henry, duke of Cornwall, and Prince Charles, duke of York. Buckingham's offices were similarly prestigious: they included master of the horse, lord lieutenant of Buckinghamshire, privy councillor (from 4 February 1617), lord admiral, justice in Eyre of all the king's forests beyond the River Trent, and keeper of Hampton Court. ${ }^{63}$

Buckingham's relations enjoyed similar rewards. His elder brother John was made viscount Purbeck (1619) and became groom of the bedchamber and master of the robes to the prince; his younger brother Charles (d.1630) became earl of Anglesey (1623) and enjoyed similar positions in the king's household; William Fielding, his brother-in-law, became viscount Fielding 
(30 December 1620), master of the great wardrobe (1622), gentleman of the bedchamber (1622), and earl of Denbigh (1622); his half-brother Edward Villiers (c1585-1626) was knighted (1616), became master of the mint (1617), comptroller of the wards (1618), and lord president of Munster (1625); and Buckingham's mother became countess of Buckingham (1618). ${ }^{64}$

So much discontent did Buckingham's promotion of himself and his family cause that the parliamentary impeachment charges against him in 1626 mentioned it. The duke's accumulation 'into his own hands' of so many government offices was interpreted as evidence of 'exorbitant Ambition' and condemned by the first article of the impeachment as being to 'the danger of the State, the prejudice of that Service ... and to the great discouragement of others; who by this his procuring and ingrossing of the said Offices, are precluded from such hopes, as their Vertues, Abilities, and Publick Employments might otherwise have given them'. ${ }^{65}$ Similarly, article eleven of the impeachment condemned his procuring of 'divers Titles of Honor to his Mother, Brothers, Kindred and Allies ... whereby the Noble Barons of England, so well deserving in themselves, and in their Ancestors, have been much prejudiced, and the Crown disabled to reward extraordinary Vertues in future times with Honor'. ${ }^{66}$

Within The Emperor's Favourite, Crispinus seeks to promote himself, his family, and his friends in much the same way as Buckingham did. Although the play only indirectly mentions Crispinus and his family acquiring titles, Crispinus makes a point of promoting his family and followers at court through the procurement of attractive marriages and offices. ${ }^{67}$ Crispinus describes his promotion of his relations as a way of sharing of his good fortune, arguing that he

$$
\wedge^{\prime} \text { cannot' think my own } \mathrm{p}^{\mathrm{r}} \mathrm{e}=
$$

ferment an happines, till $\mathrm{yo}^{\mathrm{u}} \&$ my friends by parta $=$ king witnes it.

In 1626, Buckingham justified his promotion of family and friends in similar terms, arguing that 'The Law of Nature, and the Kings Royal Favor, he hopeth, will plead for his excuse; and he rather believeth he were worthy to be condemned in the opinion of all generous minds, if being in such Favor with his Master, he had minded onely his own advancement, and had neglected those who were nearest unto him'. ${ }^{68}$ 
That Crispinus intends to promote the fortunes of his family is made clear early on in a letter to his mother. Locusta proudly notes that Crispinus has already begun to act on his words, boasting,

I sent seuenteen wenches vp in a wagon at one time; $\&$ theres great probability they shall be all Ladyes, yo ${ }^{\mathrm{u}}$ shall see in the mids of his ho ${ }^{\mathrm{r}}$ how he did not forget his freinds.

Buckingham was accused of exploiting his power as royal favourite, with the encouragement of his mother, to promote the fortunes of his kinswomen in precisely this way. In 1621 Sir John Chamberlain alluded to this practice, writing of the countess of Buckingham, 'she is to be commended for having such a care to preferre her poore kinred and frends, and a speciall worke of charitie yt is to provide for younge maides, whereof there be sixe or seven more (they say) come lately to towne for the same purpose. ${ }^{69}$ Other contemporaries viewed such matchmaking efforts less charitably. Historian Anthony Weldon (c1583-1648) specifically complained about Buckingham's summoning 'up all his Country kindred' in order to marry them richly. ${ }^{70}$

Just as Buckingham advanced the interests of numerous male kinsmen and friends by securing them lucrative government offices and rewards, so Crispinus promises to reward his kinsmen with court positions. Crispinus arguably goes a step further than Buckingham, however, promising that 'his kinsmen' shall 'at ... their own plesure / dispossess other men \& step into their places' (2.1.679-80), whereas Buckingham appears to have used a combination of persuasion and bribery to get people to give up their offices to him or those he patronized. ${ }^{71}$ Crispinus is ready to promote his relatives ahead of those who are more worthy and able. Nowhere is this clearer than in his lobbying for his brother-in-law Cesonius to be made commander of the army sent to relieve Tigranes in Armenia rather than the more able and experienced soldier Rabellius. As mentioned above, Cesonius proves a poor commander, and the mission ends in failure. Contemporaries feared that Buckingham was similarly guilty of favouring less able and worthy men simply because they were his relations or supporters, sometimes with costly consequences, as when he nominated his brother-in-law to lead the failed expedition to relieve the protestant Huguenots of La Rochelle in 1628.

Further evidence of Crispinus's abuse of his power as a court patron is arguably found in act 4 scene 2 when he is petitioned by two would-be monopolists, a goldsmith and a mat maker, seeking patents authorizing them to 
license those who practice their trades. In alluding to monopolies the playwright borrows from the world of early modern England, where the system of monopolies and patents was infamously corrupt and had been a source of contention since the latter part of Elizabeth I's reign. As Roger Lockyer explains, monopolies were 'grants made to one or more individuals, giving them the sole right to manufacture or trade in a specified commodity', while letters patent 'authorised the grantees to enforce some particular branch of royal authority, in return for payment. ${ }^{72}$ Complaints about the system reached a peak in 1621, when monopolies became one of the most hotly debated topics at the parliament of that year (30 January 1621 to 6 January 1622) and resulted in the trial of one of the most notorious abusers of the system, Sir Giles Mompesson (1583/4-after 1651), the brother-in-law of Sir Edward Villiers who had been granted the patent for licensing inns. As Mompesson's detractors revealed, he had 'charged exorbitantly for licences, opposed reforms, prosecuted no less than 7,320 innkeepers for breaches of obsolete statutes ... and, in the single county of Hampshire, had licensed sixty inns, sixteen of which had been previously closed by the justices as disorderly houses. ${ }^{73}$ Buckingham was not a 'major monopolist', but several of his relations were, having obtained profitable patents through his influence, including his half-brother Sir Edward Villiers, who was granted a monopoly for the manufacture of gold and silver thread. ${ }^{74}$ In The Emperor's Favourite, Crispinus does not appear to be a monopolist, nor does he award patents to the petitioners who visit him. His delegation of the role of overseeing the petitions to his mother is, however, similarly irresponsible and Locusta's acceptance of a ring from the goldsmith who petitions her invites interpretation as a bribe, highlighting the kinds of abuse to which the monopolies system was open and the favourite's implication in its corruption. ${ }^{75}$

Accepting gifts of the kind received by Locusta in return for patronage was not unusual in the Renaissance, nor was it necessarily regarded as corrupt, but Crispinus does not confine himself to the acceptance of such offerings. The playwright makes it clear that he is both ready to pay bribes to accomplish his own ends - as when he plans to pay men to speak against Aurelia at the High Commission (5.1.3417) — and willing to accept them. Indeed, he boasts about the fact that he is secretly in the pay of Rome's enemies:

there's not a forraine state

$\mathrm{w}^{\text {th }}$ whom Rome hath a difference but keeps

Me in continuall pay. 
In showing Crispinus to be a traitor to his state, the Newdigate playwright confirms his selfishness and corruption and thus demonstrates the dangers of concentrating favour in the hands of one courtier. He also possibly alludes to some of the most damaging allegations made against Buckingham.

Like Crispinus, Buckingham was rumoured to have collaborated with England's enemies, including Spain and France. In the early 1620s, when he supported a Spanish marriage for Prince Charles, some believed that he was a crypto-Catholic in the pay of Spain and that this was a factor in England's failure to intervene decisively in Bohemia and the Palatinate to defend Princess Elizabeth (1596-1662) and her husband, Frederick, the elector Palatine (1596-1632), against the Spanish-Hapsburg alliance. ${ }^{76}$ Indeed, in 1626 the earl of Bristol claimed that 'the Duke hath been in great part the Cause of the ruine and misfortune of the Prince Palatine and his Estates, in as much as those Affairs had relation unto this Kingdom'. ${ }^{77}$ It is possible that the Newdigate playwright saw in the Armenian wars, as told in Tacitus, a potential model for events in Bohemia and the Palatinate. Tigranes, the deputy whom Nero installs in Armenia in place of Tiridates, could be seen as a figure for Frederick, elected by the Bohemians as king following their deposition of Archduke Ferdinand of Austria as their monarch (1618). Tigranes's shortlived reign mirrors Frederick's brief reign in Bohemia, while the help offered Tiridates in reclaiming the Armenian throne appears analogous to the support Spanish troops offered Ferdinand when he invaded the Palatinate in September 1620. Read in these terms, the noble characters' championing of military action to help Tigranes's cause arguably reflects and endorses the position of those courtiers and parliamentarians who argued that England should support the elector Palatine against Ferdinand.

Anxieties about Buckingham were reinforced by the fact that he was later believed to have collaborated with the French and their leading minister Cardinal Richelieu. One of the parliamentary charges against Buckingham in 1626 was that he had proceeded with the loan of English ships to the French in 1625 knowing that they were to be turned on the French Huguenots in La Rochelle rather than to blockade the Spanish-held port of Genoa. Some hinted that the duke had repeatedly undermined England's military operations in Europe, thus causing the string of failures at Cadiz, the Île de Rhé, and La Rochelle. ${ }^{78}$ There is no evidence that Buckingham ever was in the pay of foreign powers, but The Emperor's Favourite's handling of Crispinus's career testifies to the power and perceived plausibility of such accusations. 
The Emperor's Favourite does not confine Crispinus's abuse of his power to the world of patronage or politics. In keeping with contemporary stereotypes of the 'favourite', Crispinus is also shown to be sexually corrupt. This was a charge levelled at Buckingham too, though arguably with less justification. ${ }^{79}$ Buckingham was reputedly a womanizer, but there does not appear to be any firm evidence of him coercing women into relationships with him or of him manipulating the separation of wives from their husbands, crimes of which Crispinus is guilty. Indeed, Crispinus's corrupted nature appears symbolically in his deliberate pursuit of transgressive sexual relationships. ${ }^{80}$ Thus he reportedly deflowers a nun, as in Juvenal (3.3.1531-4); he attempts to coerce his sister-in-law into an incestuous relationship with him (3.4.1648-52); he apparently seduces Roman wives at 'late suppers' (5.1.3078); he claims to use mean men's wives to manipulate their husbands (3.2.1237-49); and he attempts to seduce Rabellius's wife Lucia after contriving to send her husband overseas (4.2.2688-90). ${ }^{81}$ As well as illustrating his moral corruption, Crispinus's unlawful lusts demonstrate his tendency towards tyranny, for he refuses to recognize social and natural laws or the rights of the women and men he abuses. The play suggests that Crispinus's predatory sexual behaviour might be construed in this politicized way when Aurelia likens him to Tarquin (3.4.1689). As Curtis Perry notes, Tarquin's rape of Lucrece was 'the paradigmatic act of royal tyranny and the founding myth of the Roman republic'. ${ }^{82}$ Just as Tarquin's sexual tyranny led to his overthrow, so the play hints that Crispinus's tyrannous conduct will lead to his.

Another aspect of Crispinus's handling of power potentially relevant to contemporary perceptions of Buckingham is the Roman favourite's implicit ambition to usurp the power and place of Nero. In 1620s England some people claimed Buckingham had usurped royal power in this way. Sir John Eliot's speech concluding the 1626 parliamentary impeachment charges against Buckingham expresses this idea, declaring that the duke 'hath drawn to him and his, the Power of Justice, the Power of Honor, and the Power of Command, and in effect the whole Power of the Kingdom'. ${ }^{83}$ In The Emperor's Favourite, Crispinus initially emphasizes his humility and gratitude to Nero for his elevation at court. He is soon revealed to be ambitious for further advancement, however, not only using his power to promote the selfish desires and fortunes of himself and his allies, as noted previously, but also to thwart the careers of his opponents. Thus when King Vologesus and Tiridates threaten Tigranes's rule over Armenia, Crispinus advocates that Nero send the favourite's incompetent brother-in-law Cesonius Petus 
rather than Rabellius to defend Tigranes because Crispinus does not wish his noble rival to be successful or to be rewarded for his service to Nero. As Cesonius's subsequent defeat and the temporary loss of the Armenian crown reveals, Crispinus's selfish misuse of power is a threat to Nero and the empire as well as to his enemies and rivals. This danger is reinforced by the revelation to the audience that Crispinus has been in constant contact with Nero's foes (4.2.2500-13) and actively colludes with Vologesus and his brother in their war against Nero's deputy in order to secure them the victory (2588-2610).

The favourite's ability to manipulate the Armenian war, and Nero's part in it, reveals his dangerous influence over the emperor. Crispinus boasts of this influence several times, including in the letter that he sends to his mother following his elevation at court. In this letter he claims to have 'Nero now in a string' (2.2.675). Further testimony to Crispinus's perceived power over the emperor is afforded by King Vologesus who claims that Crispinus, rather than Nero, is 'the head of motion' in Rome ' $\&$ forbids / Or furthers all things as he standes ... 'affected" (3.1.1152-3). Contemporaries feared that Buckingham exercised a similar control over the policies of King James and King Charles and that this was what led the Stuart monarchs to make unwise, unpopular political decisions.

The play suggests that by granting one courtier so much power and influence, Nero breeds a potentially dangerous rival for himself. Crispinus's readiness to betray Nero demonstrates his disloyalty and arrogance, while his potentially treacherous sense of superiority is revealed when he claims a litter intended for the emperor. The craftsman's willingness to give the litter to Crispinus leads the emperor's favourite to conclude that the 'mechanicks / Ioyners and manuall ... $\wedge^{r}$ tradesmen doe acknowledge me / A greater man then Nero' (3.2.1396-8). Crispinus's usurpation of the king's litter recalls similar rumours about Buckingham being carried in a litter while the king walked alongside him in early 1627, an incident that likewise suggested an inversion of power and hierarchy between favourite and ruler.

Tigranes's assassination cuts short Crispinus's career and prevents him from accomplishing any further deeds of treachery. The play makes it clear, however, that a leader who disproportionately rewards and favours any individual can expect to be betrayed, misled, and potentially overthrown by his 'favourite'. The same possibility and fear underpinned the debates regarding Buckingham in the 1628 parliament and the remonstrance finally prepared against the duke. On 5 June 1628, John Newdigate recorded the 
anxious speech of Edward Kirton, who claimed that the duke 'hath gotten the strength of the kingdom into his hands; he endeavors to make us slaves; he connives at our enemies; and in my conscience has some dangerous plot upon us. ${ }^{84}$ The remonstrance against Buckingham closed with the request that 'your most excellent Majesty will be pleased to take into your Princely consideration, whether in respect the said Duke hath so abused his power, it be safe for your Majesty and your kingdom, to continue him either in his great Offices, or in his place of nearness and Counsel about your sacred Person'. ${ }^{85}$ In this context, critics might see The Emperor's Favourite as a play in the same tradition as the 'mirror for magistrates' tales, aiming to present political and moral lessons about the dangers of favouritism and tyranny by dramatizing ill examples of rule and the wielding of power. ${ }^{86}$

\section{Charles I, Absolute Rule, and the Rights of the Subject}

When Sir John Eliot likened Buckingham to Sejanus in 1626 he not only offended the powerful duke but also his master for, as Charles reputedly noted, 'If the Duke is Sejanus ... I must be Tiberius'. ${ }^{87}$ In similar fashion, in presenting Crispinus as a figure for Buckingham, The Emperor's Favourite implicitly, and potentially more controversially, invites audiences to compare Nero to Charles I. ${ }^{88}$ The pertinence of the inferred parallel is arguably reinforced by the fact that the Newdigate Nero, like Charles I and his father before him, believes that he has been divinely appointed and advocates absolute rule. In 1620s and 1630s England, the respective duties and rights of loyal subjects and their rulers were highly topical issues that featured prominently in the 1620s parliamentary debates. Like Crispinus, the Newdigate Nero becomes a figure through whom the playwright can explore contemporary anxieties about the rule of the Stuart kings generally and Charles I specifically.

In the play's opening act, Nero makes clear his belief in his divine election and in his absolute power, claiming that the 'disposeing of all things' in Rome was 'comitted by $y^{\mathrm{e}}$ Gods to me' $(1.1 .81,82)$. Similarly, he argues that 'Kings must direct their sub ${ }^{\text {ts }}$, they obey / In duty ... '\& in silent' execution' (183-4), adding that

The meanest man in Rome comands his slaue

And guies no reason why, $o^{r}$ priuiledge

Sure goes as farr as his. 
For much the same reasons, Nero counsels subjects against questioning or criticizing their rulers, arguing that 'mortalls on earth may see $\mathrm{y}^{\mathrm{e}}$ spheres turn round / But not the hand $\mathrm{y}^{\mathrm{t}}$ moues them' (169-70) and that people should 'Admire, not censure greatnes' (180), not least because, in his view, 'Emperor ${ }^{s}$ $\&$ kings are furnish $<\mathrm{e}>\mathrm{d} / \mathrm{w}^{\text {th }}$ more discerning mentall faculties' than ordinary men (3.5.2006-7). Likewise, he argues that kings are 'aboue the law' (4.3.2301) and that the 'same law is restrictiue to the $\operatorname{sub}^{\mathrm{t}} /$ That giues the prince ... 'a' spacious scope \& freedome' (1.1.439-40).

James I wrote about the special rights of kings in much the same way, arguing, for example in a verse condemnation of libels, that subjects should only 'Wounder at Kings, and them obey' and, elsewhere, that they owe a duty to their sovereign 'as to Gods Lieuetenant in earth, obeying his commands in all thinges, except directly against God, as the commands of Gods Minister, acknowledging him as a Iudge set by GOD ouer them, hauing power to judge, but to be judged onely by GOD'. ${ }^{89}$ Likewise, he argues that a good king 'although he be aboue the lawe, will subiect $\&$ frame his actions therto, for examples sake to his subiects, and of his owne free will, but not as subiecte or bound thereto..$^{90}$ By contrast, although most contemporaries appear to have accepted that 'the king of England was accountable only to God, and therefore irresistible ... and that he possessed certain "absolute" (discretionary) powers', they also generally believed that 'he was bound to govern legally, at least in certain matters. ${ }^{91}$ Glenn Burgess argues that those who suggested, like James I and the Newdigate Nero, that kings 'were not bound to rule in accordance with the law of the land' were 'rare'. 92 James generally ruled legally in practice and in 1609 reportedly said to parliament 'that he was not a king, but a tyrant, that should govern otherwise than by law. ${ }^{93}$ Similarly, although Nero claims the right to order his subjects as he sees fit, he also emphasizes the importance of subjects' consent in their rule, suggesting that he rejects tyranny. Thus he observes to Tiridates that the

obligaćons of inferior men

Make them stoop low to ma ${ }^{\text {tie }}, \&$ glory

Vsurps the names, except a full consent

Of many by their suffrage doe bestow it.

Likewise, Nero argues that

$$
\begin{aligned}
& \text { all fame } \\
& \text { Is ... } \wedge^{\prime} \text { 'wrong' acquired ... from a forcd ... 'applause' }
\end{aligned}
$$


And taken by strong hand from timorous men

If vertue doe not make a ioynd concordance

Of vnconstraynd ... assent.

Nonetheless, the play recognizes that Nero's model of rule is potentially tyrannical. Several characters suggest that there are, and should be, limits to the monarch's power over the law and the individual. In the play's opening scene, when Corbulus and Rabellius discuss Nero's assertion of his privilege, Corbulus argues, 'Twas wrong inferrd / And Roman neuer spake so to a Roman' (1.1.461-2). Stuart opponents of absolute monarchy made similar arguments about the limits of the royal prerogative and the importance of preserving the liberty of subjects. As Martin Butler notes, Charles's parliaments 'returned obsessively to the disregard demonstrated by his impositions, forced loans, monopolies and arbitrary imprisonments for the constraints of law and the essential, unimpeachable liberties of person and property which law should guarantee for the subject', and they adopted similar imagery of slavery to represent the position of subjects should these liberties be denied. ${ }^{94}$ Sir Dudley Digges asserted in the House of Commons that the 'Monarch yat doth not maintain ye rights of ye subiects is a Monarch of none but slaues and vassals' (22 March 1628) and Mr Saunders argued that 'The King hath his priuiledges, ye subiect hath his right.... Liberty is ye subiects inheritance' (29 March 1628), as John Newdigate recorded in his parliamentary diary. ${ }^{95}$

The Emperor's Favourite's honourable and virtuous characters similarly emphasize the liberty of the subject. In act 2, when Nero joins Crispinus in trying to persuade Aurelia to marry Crispinus's simple-minded brother Hillarius, Aurelia resists their arguments, asserting that

Cesar is $\mathrm{m}^{\mathrm{r}}$ of my life \& may

Comand. . it freely, but my vnlimited mind

He nether can restrayn by strait coaction

Nor guie a largenes to.

Similarly, Aurelia later rejects Crispinus's tyrannous attempt to coerce her into an incestuous, adulterous relationship with him: 'Great $S^{r}$ I scorne to be / A traytor to my selfe or ... $\wedge^{\mathrm{r}}$ whore to thee" (3.4.1701-2). Borrowing from the language of treachery, Aurelia demonstrates that Crispinus's attempted seduction has a political as well as a personal significance, for it infringes on her liberty as a subject, as well as on her honour as a woman, and is an abuse of his power. ${ }^{96}$ This theme is in line with several Stuart plays in 
which the rape and unlawful appropriation of women acts as a symbol of the tyrannous exercise of power. In Philip Massinger's The Roman Actor (printed 1629), a play that shares a number of features with The Emperor's Favourite, Domitianus Caesar forces Aelius Lamia to divorce his wife in order that he might marry her, demonstrating his disregard for the law and the rights of subjects in precisely the same way that Crispinus's attempted seduction of Aurelia does. ${ }^{97}$

\section{Obedience vs Resistance}

In its implicit identification of absolute monarchy with tyranny and its fashionable critique of royal favouritism, The Emperor's Favourite belongs to the tradition of anti-court drama that flourished in Stuart England. ${ }^{8}$ On the surface, it might seem less radical than some of those works. ${ }^{99}$ Despite his flaws and their concerns about his rule, Nero's critics consistently emphasize the importance of duty and obedience to the emperor, and they generally choose to be silent rather than resist him. Blair Worden suggests that this is fairly typical of plays featuring corrupt favourites in this period, arguing that 'few of the enemies of tyranny see legitimate means of resisting its advance' and observing that 'most of them are instinctively loyal even to the most oppressive of kings. 100 Thus when the Newdigate Nero asserts his right to command his subjects as he pleases (1.1.183-7), Rabellius and Corbulus both object to his asserted privilege, but they do not dispute it. On the contrary, as Corbulus explains, 'duty' made me ... silent' (1.1.463). When Nero asks Rabellius to take over the army in Armenia, Rabellius accepts the post in an equally loyal fashion, despite his reluctance to take on the mission, observing, 'My duty liues in silence' (4.2.2456). Read in topical terms, the emphasis on duty suggests that the play's author was loyal to monarchical government and that he sought the reform rather than the overthrow of the Stuart king, like many contemporaries. This loyalty to the monarchy is not surprising. As Roger Lockyer notes, 'the political assumptions of the day provided no alternative to royal rule'. ${ }^{101}$ This fact might also explain why the play does not dwell on Nero's tyranny or tell the story of the emperor's overthrow and suicide, focusing its attack instead on the corrupt court favourite. ${ }^{102}$ The play reserves its most trenchant and explicit criticism for Crispinus, who is perceived to have led the emperor astray, as is reflected when Rabellius observes that 'Cesar is good I would the men about him / were as good seruants as he is a maister' (3.5.1936-7). 
Those discontented with Stuart rule in the 1620s concentrated their criticism on the duke of Buckingham in much the same way. To do so was safer. Such focus on the favourite reflects the fact that many contemporaries were persuaded that the duke was responsible for the country's perceived ills. As Roger Lockyer notes, there 'was nothing consciously hypocritical about their attitude'. In a culture in which 'it was axiomatic that the King could not be responsible' for the country's ills, 'the blame must rest on his favourite'. ${ }^{103}$ The Newdigate playwright acknowledges this tendency, having Datus observe that when affairs go ill in the state often 'The fauourites haue the blame, $y^{\mathrm{e}}$ kings stand free / In worth \& iudgem ${ }^{\mathrm{t}}$, to the vulgars eye (1.1.373-5). This habit of blaming favourites rather than their royal masters is why in the contentious parliaments of 1626 and 1628 Buckingham bore the brunt of MPs' complaints about the current regime while the king was generally excused from blame, at least overtly. The text of the 1628 remonstrance presented against Buckingham, which implicitly excused Charles, argues that 'we do verily believe that all, or most of these things which we shall now present unto your Majesty, are either unknown to you, or else by some of your Maiesties Ministers offered under such specious pretences, as may hide their own ill intentions, and ill consequences of them from your Majesty'. Instead, they claimed that the 'principal cause' of the 'evils and dangers' to the kingdom was the 'excessive power of the Duke of Buckingham, and the abuse of that power. ${ }^{104}$ On the other hand, as at least some members of the 1628 parliament recognized, they could not attack the royal favourite without indirectly attacking his master. ${ }^{105}$ Charles had said as much in the statement that the lord keeper made on his behalf to the 1626 parliament as it prepared to impeach Buckingham: 'his Majesty cannot believe that the aim is at the Duke of Buckingham, but findeth that these Proceedings do directly wound the Honor and Judgment of himself'. ${ }^{106}$ One of the duke's supporters drew a similar conclusion, warning Charles that 'this great opposition against the Duke, was stirred up and maintained by such as seek the destruction of this free Monarchy', who 'Because they finde it not yet ripe to attempt against the King himself, they endeaver it through the sides of the Duke. ${ }^{107}$

In this context, it is perhaps significant that The Emperor's Favourite does not exempt Nero from criticism. The play opens, for example, with Rabellius and Corbulus lamenting the condition of the state and Nero's court. Both are thus implicitly critical of the emperor, as is reflected in Rabellius's mocking allusion to the fact that 'the Emperour brags the state was neu ${ }^{\mathrm{r}} /$ 
Gouer'nd with less corruption' (1.1.48-9) and in Corbulus's suggestion that Nero's plan to make him proconsul in Syria is potentially double-edged:

when I call to mind that smallest rubs

make great men stumble or that Damocles

was set in state \& had a sword hung ore him

In a horse hayre, I $\mathrm{p}^{\mathrm{r}}$ sently conclude

He sate in danger, \& the power intrusted

To me, is but a ... 'speedy' way to ruine.

Corbulus is similarly troubled by Nero's angry reaction when he asks not to be sent to serve in Syria (450-63) and Rabellius expresses scepticism about the extent to which Nero delegates his power by making Tigranes his deputy in Armenia (465-77). Rabellius is also ready to qualify Nero's assertions about his skills as ruler, as when Nero asks him if he ever errs in his imperial judgments. Rabellius's reply - 'Seldome when things are not too farr below yo $^{\text {u' }}$ (304) - is polite but indicates that Nero can and does make misjudgments. As in Caroline England, in Nero's Rome there are concerns that good men are overlooked or punished by being sent on service abroad while the unworthy are rewarded at home (507-45). ${ }^{108}$ At least one of the historical Nero's reputed 'crimes' is also alluded to in the play - his alleged poisoning of his predecessor (4.2.2277-9) — an allegation that may have been included because of its veiled relevance to Charles I. Although no one alledged that Charles poisoned James I, some believed Buckingham did; in his 1649 trial, Charles was accused of preventing the investigation of James's death to protect the duke. ${ }^{109}$

It is perhaps equally important to note that the play does not rule out resistance to tyranny or the overthrow of tyrants. Nero's loyal Romans may not choose to rise up against him, but they do conspire against his favourite who, in his increasingly tyrannical behaviour, mirrors and exaggerates Nero's own tyrannical tendencies. As those men loyal to Rome confer about the problem Crispinus's abuse of power poses, we can see the play exploring the options open to subjects faced with tyranny. This includes openly debating whether it is right to kill Crispinus (5.1.3104-30). Corbulus initially concludes that it would be a $\sin (3123)$, whereas Rabellius argues,

I am an heretick in that point

The best in Rome think him the onely man 
That seekes ... the vtter ruin of the state

And to subuert the gouerm ${ }^{\mathrm{t}}$.

Corbulus consequently concedes that 'though't be sin to ... 'kill' a loyall $\operatorname{sub}^{t} /$ To cut a traytours throat is meritorious' (3129-30), and both men vow to support Tigranes as he declares his intention to obtain satisfaction from Crispinus, with Rabellius declaring that Tigranes's 'resolue is Roman' (3179). Even at this stage it is not clear if Tigranes will resort to violence. Before turning to his sword, he, Rabellius, and Corbulus warn Nero about Crispinus's treachery (5.2.3531-43), and they counsel the emperor to lessen the favourite's power (5.3.3735-41). When they finally confront Crispinus, they give him the option of surrendering his power and offices

To those men we three think conuenient

And so liue quiet, \& auoid the trial ...

That must condemn $\mathrm{yo}^{\mathrm{u}}$, if $\mathrm{yo}^{\mathrm{u}}$ be brought to it.

$(3768-70)$

In much the same way, the 1626 parliamentary impeachment of Buckingham sought to warn Charles about the power and alleged treachery of his favourite, and in the 1628 parliament Sir James Perrot specifically suggested that Buckingham give up his public offices. ${ }^{110}$ Only when Crispinus spurns Tigranes's similar proposal does the frustrated soldier stab him. The play thus presents violence as the last resort but an available one for those oppressed by a tyrant.

The initial responses to Crispinus's assassination are, again, revealing in their recognition of the contentiousness of Tigranes's act. For Rabellius and Corbulus, it is 'justice' (5.3.3803); for Pronus and Commodus, Crispinus's friends, it is 'murder' (3802). The assassin presents himself as a 'sacrifice for ... libertye' (3857) and attributes his success to Justice:

Thanks Iustice

Thou art the best directer, $\&$ this hand

The comon wealth will pray for.

There were similar variations of opinion in the flood of responses to John Felton's assassination of Buckingham. Most contemporaries appear to have welcomed the duke's death, and a number of Felton's defenders alluded to his 'inspired "hand" and "arm"', 'perhaps trying to detach the assassination from a private person and give it an independent force as an act of God or violated nature. ${ }^{111}$ On the other hand, there were contemporaries who condemned 
Buckingham's assassination. ${ }^{112}$ 'A charitable censure on the death of the D. of B.' ends with the statement that 'Felton, sure thou art too blame, / By whose strong hand our George was slaine', while Thomas Carew's elegy for Buckingham, 'Readers when these dumb stones have told', alludes to Felton's 'murd'rers knife.'113 In this light, it is intriguing that The Emperor's Favourite closes by focusing on Crispinus's mourning family and Datus's flattering account of the 'noble' favourite's tragic death (5.3.3899) rather than on the favourite's opponents. The difficulty of knowing whether the play expects its audience to endorse the slaying of Crispinus is arguably compounded by the fact that there is no epilogue. While the text has suggested the necessity of his overthrow, it leaves the acceptability of the favourite's murder, perhaps deliberately, ambiguous. Equally, the voicing of the views of Crispinus's supporters following his death (and, by implication, those of Buckingham's supporters) may be seen as another example of a contemporary interest in juxtaposing opposing views of leading political figures and events.

The fall of Buckingham did not end contemporary anxieties about the Caroline state. On the contrary, Charles's subsequent decision to rule without parliament for more than a decade (from March 1629 until April 1640) led to heightened concerns about his government, while his favourite's death meant that there was no longer a ready scapegoat for Charles's unpopular policies. ${ }^{114}$ Likewise, Crispinus's fall does not fully allay the anxieties that The Emperor's Favourite has raised about Nero's tyrannical inclinations or his conception of himself as divinely appointed and above the law. ${ }^{115}$ This, combined with the notoriety of the historical Nero's fall, means that the play offers an implicit, prophetic warning about the fate that could await Charles should he continue in the 'tyrannous' ways of a Crispinus or a Nero. In its implicit equation of absolute rule with tyranny and in its unresolved anxieties about its ruler, the play arguably foreshadows the increasingly sensitive debates about absolute monarchy that would emerge in the 1630s and parliament's eventual overthrow and condemnation of Charles I in 1649 as a 'Tyrant' who had sought 'to overthrow the Rights and Liberties of the People. ${ }^{116}$ More contentiously, like the many libels on Buckingham in the 1620s, The Emperor's Favourite, and other Stuart Roman history plays it resembles, arguably reflected and contributed to the creation of a 'moral universe' in which the overthrow of the monarch, like the assassination of the duke, would become 'both imaginable and desirable'. 117 


\section{Politics Out of the Closet?}

Renaissance manuscript plays written by amateur playwrights have often been described as 'closet' dramas, the assumption being that they were intended for reading rather than performance, yet all four of the Arbury plays appear to have been written with the possibility of staging in mind, as Trevor Howard-Hill notes. ${ }^{118}$ One of the first indications of staging in The Emperor's Favourite is to be found in the cast list, which groups the female roles under the subtitle 'Women speakers' (1 15). This phrase points to the tantalizing possibility of spoken delivery and female performance. In equally suggestive fashion, the prologue speaks in the plural, as though on behalf of a troupe of actors, and uses metaphors of sight and physical action when alluding to the forthcoming drama:

Sueton \& others shew the passages

That fill the other scenes, \& we professe

To walk by their direction. You shall see

Tigranes fate twice chang'd.

The stage directions that occur in the Arbury plays afford more substantial evidence of a concern with the practicalities of performance. Each play carefully marks entries and exits of characters with stage directions, some of which allude to the use of doors as entry and exit points. ${ }^{119}$ Thus in act 4 of The Emperor's Favourite, the exit of Tiridates is shortly followed by a direction that reads, 'Enter Pronus at / 'the other dore'" (4.2.2644-5). Elsewhere, the directions of The Emperor's Favourite refer to the 'stage' (5.1.3268), suggesting that the playwright imagined a performance on a platform backed by at least two doorways, akin to those mounted by professional players in the London theatres. Nero's allusion to holding 'vp the hanging' (4.2.2491) so that he might exit with Hillarius indicates that the playwright also imagined covering at least one exit with the kind of hangings occasionally used in the metropolitan theatres. The playwright shows a similar attention to the pragmatics of performance by incorporating detailed directions for the introduction of necessary properties, including a chair, letters, six muskets, a live pig, a litter with a door, a horn, a halter, a watch, a beard, a box, and a crown.

There is no evidence of any professional or amateur performances of The Emperor's Favourite, although it is possible such performances, especially amateur ones, escaped record. Other country houses in the early modern period offered staged readings and amateur performances, for instance Surrenden, 
the Kentish home of Sir Edward Dering, in the 1620s and Apethorpe, the Northamptonshire home of Mildmay Fane, second earl of Westmorland, in the 1640s. ${ }^{120}$ Similar performances could have occurred at Arbury Hall or another Newdigate house. In her article on The Humorous Magistrate, M.J. Kidnie describes the seventeenth-century Newdigates' connections with local gentry families such as the Burdetts of Foremark near Repton and the Willoughbys of Middleton Hall, pointing to the possibility that the Arbury manuscripts and live performances were shared with such friends. ${ }^{121}$ Evidence that this was the kind of 'performance' or reading that the playwright envisaged may be found in the other Arbury plays. The epilogue of The Twice Chang'd Friar alludes to its seated, possibly tired spectators, noting that 'your vneasie seats' may 'haue tyr'd you so / You're glad to leaue 'hem', and that their 'eies' may 'Be weary as' their 'eares', before asking that they forgive the author for the play's errors and that they relieve themselves by clapping: 'If your applausiue hands vouchafe to shew / You grace the author as he honours you' (f 229v). In similar fashion, the epilogue to Ghismonda and Guiscardo describes the audience as 'you whose goodnes names you noble freinds', and it ends with the playwright's statement that 'you will please him much if your hands say / You are delighted with his tragick play' (f 102v). By implication, the playwright expected his plays to be heard, seen and, he hoped, applauded by an audience of friends. ${ }^{122}$

Whether or not the play was performed, it is likely that others in Newdigate's circle read it. The marginal markings found on the manuscript of The Emperor's Favourite and the other Arbury plays could be the work of such a reader or readers. ${ }^{123}$ Members of the early modern gentry customarily shared literature, especially texts of a topical nature, with family and friends, and the Newdigates were no exception, as Gilbert Sheldon's letters to Newdigate and the survival of various topical texts and contemporary verses amongst the family's early modern papers demonstrate. The Arbury plays may have passed among friends in the same way. A scribal copy of one of the Arbury plays (Ghismonda and Guiscardo) preserved in British Library Additional MS 34 (ff 139-86) points to the circulation of this play beyond the Newdigates. ${ }^{124}$ The British Library copy of the play is bound in a book that carries the bookplate of Sir John Dolben of Finedon (1684-1756). ${ }^{125}$ It is possible that the manuscript came into Dolben's possession via the family's links with Gilbert Sheldon, the Oxford-based friend with whom we know Newdigate regularly exchanged literature. When Sheldon died, he left a number of items from his private library to his nephew Gilbert Dolben (1658/9-1722), father 
of Sir John Dolben. ${ }^{126}$ There is certainly other evidence of Gilbert Sheldon's papers passing to Sir John Dolben and his descendants, presumably via Dolben's father. ${ }^{127}$ The association of a second manuscript of The Humorous Magistrate (University of Calgary Special Collections, Ms C132.27) with Watnall Hall, the Nottinghamshire home of the Rolleston family, points to the possible circulation of this play in manuscript too, as does a note in the left-hand margin of one of the pages of the Arbury Hall manuscript of the play: 'Dr $S$ this speach not so cleare \& perspicuous' (f 106). ${ }^{128}$ This annotation suggests that Doctor ' $S$ ' had been given the play, or a copy of it, for comment. Assuming the play's author was John Newdigate III, this could be another allusion to Gilbert Sheldon. If Sheldon was presented with a copy of Ghismonda and Guiscardo, and was invited to comment on The Humorous Magistrate, it is possible that Newdigate shared the other Arbury plays with him too, including The Emperor's Favourite, which might have been of special interest to the Oxford don given his taste for topical gossip and his interest in the career of Buckingham. A later royalist, Sheldon might have found the play's criticisms of the Stuart regime troubling, but he would probably have approved of the overt emphasis upon the importance of duty to one's monarch.

\section{Conclusions}

The Emperor's Favourite may be a little-known play, but it reveals much about the society in which it was produced, confirming the value of considering literary and manuscript texts as we seek to learn more about the politics and culture of Caroline England. The play provides fresh proof of its contemporaries' habit of using classical history to comment obliquely on the present, even when working beyond the immediate control of the censors, and it yields new evidence of regional attitudes to some of the key political topics in Caroline England: the duke of Buckingham, court favourites, absolute rule, and the rights of subjects. It shows that these were matters of intense concern outside of, as well as within, the metropolis. Possibly written early in the years of Charles's personal rule, The Emperor's Favourite suggests that, long before the fall of Charles I, contemporaries were reflecting upon the political tensions about royal prerogative powers and the rights of subjects, with potentially radical consequences in the provinces as well as in the capital. As well as offering a devastating critique of Buckingham's alleged political and sexual corruption and his malign influence over his royal patrons, The Emperor's 
Favourite makes the broader case that concentrating favour in the hands of any one individual is dangerous both for the ruler and his state. It challenges any ruler's right to 'absolute' power over his or her subjects, too, suggesting that to assert that one is above all laws is to claim a potentially tyrannical authority at odds with respect for the rights and liberties of the subject.

By using Roman history to 'touch .... $\mathrm{p}^{\mathrm{r}}$ sent' (5.2.3592) times, and by focusing its attack on court corruption and tyranny as personified by the royal favourite, The Emperor's Favourite is characteristic of Stuart Roman history plays and anti-court literature of the period, and it mirrors the parliamentary attacks on Buckingham in the 1620s. In its overt emphasis on the importance of duty and obedience to the ruler, the play likewise recalls the 'deferential rhetoric' and professions of loyalty with which the parliamentarians of the period presented their complaints to Charles I and reminds us that critics of the Caroline court and of absolute rule were not necessarily or inevitably opposed to the monarchy. ${ }^{129}$ On the other hand, the readiness with which the play's virtuous characters eventually pursue the overthrow of Nero's autocratic favourite points to a culture in which the deposition of tyrants and their 'creatures' was increasingly both 'imaginable' and defensible. ${ }^{130}$ In this respect, The Emperor's Favourite affords further reason to question the arguments once made by historians such as John Morrill that political polarization and allegiance to an organized opposition was exceptional outside of London before the 1640s and that the so-called silent majority' of rural Englishmen remained passive and politically neutral on the eve of the English civil war. ${ }^{131}$ On the contrary, like the anti-Buckingham poems composed by neighbouring East Midlands peer John Holles, first earl of Clare, The Emperor's Favourite suggests that at least some members of the rural Caroline elite were far from being neutral or silent, not only collecting topical and oppositional political literature, but themselves actively engaging in radical attacks on the Stuart regime, long before the overt politicization of English society and the outbreak of civil war in the early 1640 s. ${ }^{132}$

In its borrowings from political gossip and contemporary political debates, as well as popular theatre and classical history, The Emperor's Favourite offers fresh proof that members of the early modern regional elite stayed in touch with metropolitan culture and events, despite being rurally-based, sometimes using drama and the other literature that they circulated and transcribed in their commonplace books and manuscript miscellanies to share their views of that culture with their peers. 
In its implied preparation for performance, and in its possible circulation within the Newdigate circle, The Emperor's Favourite makes clear that the period's manuscript dramatists, like its poets, were not necessarily writing solely or primarily for the 'closet' either. For at least some of the period's amateur playwrights, including the author of The Emperor's Favourite, drama was a medium for exploring topical issues and debates as well as for recreation. Plays may have been valued all the more when 'the debates of the Houses of Lords and Commons' were 'temporarily silenced' in the 1630s. ${ }^{133}$ Like the works of the professional playwrights, manuscript plays such as The Emperor's Favourite may even have helped to shape Caroline political culture beyond the metropolis and thus invite the further attention not only of literary scholars but also of historians of the period keen to learn more about the 'political consciousness' and views of the regional gentry prior to the English civil war. ${ }^{134}$

\section{Notes}

This essay expands on research undertaken for my Malone Society edition of The Emperor's Favourite (Manchester, 2010). I express my thanks to the Malone Society for permission to draw on some of the material incorporated in the introduction to the edition. I also wish to thank Lord Daventry for depositing Arbury ms A414 on extended loan at WCRO and for granting me permission to quote from it. Finally, I am grateful for the valuable suggestions made by the editors and the two anonymous readers who reviewed the essay for Early Theatre. Any errors remain, of course, my own.

1 On the occasional tensions between Charles and Buckingham while James was alive, see Roger Lockyer, Buckingham: The Life and Political Career of George Villiers, First Duke of Buckingham, 1592-1628 (London, 1984), 33-4.

2 See James Holstun, Ehud's Dagger: Class Struggle in the English Revolution (London, 2000), 157, 187, 159.

3 Mario DiGangi, 'A Beast So Blurred: The Monstrous Favourite in Caroline Drama', Adam Zucker and Alan B. Farmer (eds), Localizing Caroline Drama: Politics and Economics of the Early Modern Stage, 1625-42 (Basingstoke, 2006), 158, 159.

4 For examples of the poetry written about Buckingham, see Frederick W. Fairholt (ed.), Poems and Songs Relating to George Villiers, Duke of Buckingham and His Assassination by John Felton, August 23, 1628 (London, 1850) and Alastair Bellany and Andrew McRae (eds), 'Early Stuart Libels: An Edition of Poetry from Manuscript 
Sources', Early Modern Literary Studies, Text Series I (2005), http://purl.oclc.org/ emls/texts/libels.

5 Andrew McRae, Literature, Satire and the Early Stuart State (Cambridge, 2004), 43; Curtis Perry, Literature and Favouritism in Early Modern England (Cambridge, 2006), 1.

6 For a selection of works concerned with early modern favouritism and its representation, see, for example, Perry, DiGangi, and J.H. Elliott and L.W.B. Brockliss (eds), The World of the Favourite (New Haven, 1999).

7 The other plays are Ghismonda and Guiscardo (ff 77-102v), The Humorous Magistrate (ff 104-43), and The Twice Chang'd Friar (ff 196-229v). With the exception of The Twice Chang'd Friar, these titles are those given to the plays by Trevor HowardHill when he published his pioneering essay on the Arbury dramas: 'Another Warwickshire Playwright: John Newdigate of Arbury', Renaissance Papers (1988), 51-62. Arbury Hall ms A414 is housed in the library of Arbury Hall, Nuneaton, where it appears to have been held since it was first bound sometime after 1702 (the date of the latest explicitly dated text). A microfilm of the ms can be consulted in Warwick County Record Office (hereafter wCro), Newdigate Family Papers (hereafter NFr), M.I. 351/3, Item 20. When quoting from the manuscript, original spelling, superscriptions, and abbreviations are retained (with the exception of the abbreviations for per and pro, which are expanded and italicized when represented in the manuscript by a modified version of $p$ ); the tilde used to mark some abbreviations is also retained; deleted text is struck through (e.g. doe); obscured text is enclosed in angled brackets (<.>); and interlined text is shown within half-brackets $\left({ }^{[1}\right)$. Quotations from The Emperor's Favourite will be cited in the text and use the act, scene, and line numbers found in the Malone Society edition of the play (Manchester, 2010); the act divisions correspond to those found in the original manuscript.

8 The play is not dated, but a possible allusion to Buckingham being carried in a litter while the king walked alongside him in early 1627 and a reference to 'Come hear, Lady Muses, and help me to sing', a popular anti-Buckingham ballad in circulation in the spring and summer of the same year, could mean that the play was started as early as 1627 . On the other hand, the parallels between the assassination of Crispinus and Buckingham's murder on 23 August 1628 would suggest that the play post-dated this event. Other allusions - including a possible reference to the Salisbury Court Theatre (first used for performances in 1630-1) and to the seventh year of Nero's/Charles I's regime - could mean that play was completed as late as 1631-32. For a fuller discussion of the dating of the play see The Emperor's Favourite, xxii-xxiv. 
9 Crispinus features in Juvenal's first and fourth Satires. See, for example, The First Six Satyres of Juvenal, Sir Robert Stapylton (trans.) (Oxford, 1644), 2, 37-9, 111. Tacitus is the main source for the playwright's treatment of the Armenian wars; Crispinus's mother, Locusta takes her name from a woman reputedly employed by Nero; and Datus is loosely based on the poet-player of the same name featured in Suetonius's account of Nero's career. See, for example, The Annales of Cornelius Tacitus. The Description of Germanie (London, 1598), 176, 222-47; The Histories of Twelve Caesars, Emperours of Rome: Written in Latine by C. Suetonius Tranquillus, Philemon Holland (trans.) (London, 1606), 195, 200-1.

10 These plays include Ben Jonson's Sejanus (London, 1605), The Stately Tragedy of Claudius Tiberius Nero (London, 1607), The Tragedy of Nero (London, 1624), Philip Massinger's The Roman Actor (London, 1629), Thomas May's Julia Agrippina (London, 1639), and Nathaniel Richards's Messalina (London, 1640). For a fascinating discussion of Stuart Roman plays, see Martin Butler, 'Romans in Britain: The Roman Actor and the Early Stuart Classical Play', Douglas Howard (ed.), Philip Massinger: A Critical Reassessment (Cambridge, 1985), 139-70, and on English playwrights' use of Roman history, see Annabel Patterson, "Roman-Cast Similitude”: Ben Jonson and the English Use of Roman History', P.A. Ramsey (ed.), Rome in the Renaissance: The City and the Myth (Binghamton, 1982), 381-94. For information about contemporary views of Seneca and Tacitus, see J.H. Salmon, 'Seneca and Tacitus in Jacobean England', Linda Levy Peck (ed.), The Mental World of the Jacobean Court (Cambridge, 1991), 169-88.

11 See Perry, Literature and Favouritism, 38.

12 Patterson, 'Roman-Cast Similitude', 382.

13 Ibid, 383.

14 Thomas Heywood, An Apology for Actors (London, 1612), no page numbers.

15 See John Rushworth, Historical Collections of Private Passages of State. Weighty Matters in Law. Remarkable Proceedings in Five Parliaments. Beginning the sixteenth year of King James, anno 1618. And ending the fifth year of King Charls, anno 1629 (London, 1659), 360.

16 On the dangers of writing verse libels, even when confined to manuscript, see Alastair Bellany, The Politics of Court Scandal in Early Modern England: News Culture and the Overbury Affair, 1603-1660 (Cambridge, 2002), 113.

17 On Charles's appropriation of imperial imagery, see, for example, Butler, 'Romans in Britain', 152, and John Peacock, 'The Visual Images of Charles I', Thomas N. Corns (ed.), The Royal Image: Representations of Charles I (Cambridge, 1999), 180, 214, 228.

18 Edmund Bolton, Nero Caesar, Or Monarchie Depraued (London, 1624), 70. 
19 Alan T. Bradford, 'Stuart Absolutism and the "Utility" of Tacitus', Huntington Library Quarterly 46 (1983), 140.

20 On Buchanan, see D.M. Abbott, 'Buchanan, George (1506-1582)', DNB (Oxford University Press, 2004).

21 Vivienne Larminie, Wealth, Kinship and Culture: The Seventeenth-Century Newdigates of Arbury and Their World (Woodbridge, 1995), 158. The Arbury plays were first speculatively attributed to Newdigate by Trevor Howard-Hill; see 'Another Warwickshire Playwright', 51-62. My own research has lent further weight to this attribution. For a discussion of Newdigate's interest in theatre and the circumstantial and paleographic evidence for his authorship of The Emperor's Favourite (and the other Arbury plays), see The Emperor's Favourite, xxvi-xxxii.

22 Larminie, Wealth, Kinship and Culture, 158.

23 See ibid, 195, 197, 198 for records of payments in the family accounts for works by Juvenal (purchased 1618), Tacitus (purchased 1619), and Suetonius (purchased 1619). We know from a letter that Newdigate received from Gilbert Sheldon in 1628 that Sheldon intended to send him an English translation of Juvenal, too. See wCro, Newdigate Correspondence (hereafter NC), CR136/B470.

24 wCro, NC, CR136/B476; wCro, NC, CR136/B477.

25 The 'Apologetic Petition' is wrongly identified as a 'Remonstrance from the Commons to Charles I' in the typewritten index that accompanies Arbury ms A414. See William Cobbett, John Wright, and Thomas Curson Hansard, The Parliamentary History of England from the Earliest Period to the Year 1803, Volume 1, 1066-1625 (London, 1806), 1333-4 for a copy of the 'Apologetic Petition'.

26 The newsletter is preserved as wCro, NC, CR136/B108. One copy of Scot's text is found in Arbury ms A391; another copy occurs in Arbury Ms A415, where it follows a contemporary manuscript copy of Thomas Goffe's play Bajazeth (see wCro, NFP, M.I. 351/3, Item 12 and Item 21).

27 Newdigate's diary is preserved as wCrO, John Newdigate's 1628 Parliamentary Diary, CR136/A1-3, and it is published in Robert C. Johnson, Mary Frear Keeler, Maija Jansson Cole, and William B. Bidwell (eds), Commons Debates 1628, 4 vols (New Haven, 1977-8).

28 Johnson, Keeler, Cole, and Bidwell (eds), Commons Debates 1628,1.27.

29 Larminie, Wealth, Kinship and Culture, 160; Bodleian Library, Oxford (hereafter Bodl), ms Eng. poet e.112, f 78v, ff 1-73.

30 wCro, NC, CR136/B470; Gill's words are cited in Holstun, Ehud's Dagger, 174. Gill was tried in the court of Star Chamber. He faced a possible fine and the loss of his ears, but instead he was sentenced 'with temporary loss of liberty and office' 
(Holstun, 174). For further information, see Gordon Campbell, 'Gil, Alexander, the younger (1596/7-1642?)', DNB (Oxford University Press, 2004).

31 See Bellany and McRae, 'Early Stuart Libels', Oi16. A manuscript copy of the ballad, in a hand resembling that found in the Arbury plays, is preserved in Brotherton Collection, Leeds University, Ms Lt q11 (on f 12). (Thanks must go to Mary Polito for drawing my attention to this copy of the ballad.) Ms Lt q 11 consists of a series of loose manuscript pages, mainly of English verse, from the early seventeenth century to the early eighteenth century. The compiler of the miscellany is unknown, but its contents match items listed by J. Harvey Bloom (c1903) as occurring in Ms A352 of the Newdigate family, suggesting that the miscellany originally came from Arbury Hall. The appearance in the miscellany of a 'Pasquill' (f 36v) accompanied by a note in what appears to be Newdigate's handwriting, dated 1636 and describing the text as having been 'Sent me from Oxford by Mr Boham Dr Sheldons man', reinforces the family's connection with Brotherton Ms Lt q11 and Sheldon. The miscellany also includes other texts that connect it with Arbury Ms A414, such as a copy of an anonymous response to the Richard Corbett poem transcribed in the latter, 'Letter to the Duke of Buckingham, being with the Prince in Spain'. This popular response opens, 'What? False on's Deanery?' (Brotherton ms Lt q 11, ff 47-47v). (See Andrew McRae, 'Satire and Sycophancy: Richard Corbett and Early Stuart Royalism', Review of English Studies 54.215 [2003], 348-9 for a discussion of this poem and its circulation.) Another copy of the anti-Buckingham ballad alluded to in The Emperor's Favourite is preserved in Gilbert Sheldon's papers, providing further evidence of shared literary interests and confirmation that 'the clean contrary way' was circulating in the cultural circles to which the Newdigates belonged in the early seventeenth century (see Bodl, ms Add. C302, ff 18-18v).

32 Alastair Bellany, "Rayling Rymes and Vaunting Verse”: Libellous Politics in Early Stuart England, 1603-28', Kevin Sharpe and Peter Lake (eds), Culture and Politics in Early Stuart England (Stanford, 1993), 289.

33 See Bellany and McRae, 'Early Stuart Libels', 349.

34 Lockyer, Buckingham, 25.

35 See The First Six Satyres of Juvenal, 2, 37-9, 111.

36 Parallels between Buckingham and Sejanus had been drawn as early as 1621. See Richard Cust, 'News and Politics in Early Seventeenth-Century England', Past and Present 112 (1986), 66-67. The name became more commonly associated with Buckingham during the Caroline era when Sir John Eliot famously likened the duke to Tiberius's favourite during the 1626 parliament. See Salmon, 'Seneca and Tacitus', 188. Similar parallels were drawn between Sejanus and infamous continental royal favourites such as Cardinal Richelieu in France. See Antonio Feros, 'Images of 
Evil, Images of Kings: The Contrasting Faces of the Royal Favourite and the Prime Minister in Early Modern European Political Literature, c. 1580-1650', J.H. Elliott and L.W.B. Brockliss (eds), The World of the Favourite (New Haven, 1999), 214.

37 See Joseph Wright (ed.), The English Dialect Dictionary (Oxford, 1905; rpt 1970), 5.578. Buckingham's mother came from a poorer branch of her husband's family and brought no fortune when they were married. As Roger Lockyer notes, Buckingham's enemies 'took delight in exaggerating her lowly origins' (Buckingham, 5).

38 Ibid, 25-6. On Newdigate's interest in horses and horse-racing see Larminie, Wealth, Kinship and Culture, 157, 165. Evidence that Newdigate was familiar with Buckingham's activities as a horse-breeder and racer is afforded by one of the letters that he received from Gilbert Sheldon in 1623, in which Sheldon alludes to the duke's horses being at the races in Brackley, a horse-racing venue that Newdigate periodically attended (see wCRO, NC, CR136/B481).

39 Roger Lockyer, 'Villiers, George, first duke of Buckingham (1592-1628)', DNB (Oxford University Press, 2004). Lockyer, Buckingham, 411.

40 Juvenal, the playwright's main source, does not mention Crispinus's fate.

41 Cited in Lockyer, Buckingham, 458.

42 Felton was executed on 28 November 1628. Holstun, Ehud's Dagger, 176.

43 For a brief account of the countess of Buckingham, see David L. Smith, 'Villiers, Mary, suo jure countess of Buckingham (c.1570-1632)', DNB (Oxford University Press, 2004).

44 On the countess's exploitation of Buckingham's power to advance the fortunes of her family, see, for example, D. Harris Willson, King James vi and I (London, 1956), 387.

45 Cited in Hugh Ross Williamson, George Villiers, First Duke of Buckingham: Study for a Biography (London, 1940), 141.

46 Richard Newdigate was later an associate of William's son Basil Fielding, earl of Denbigh. Vivienne Larminie, 'Newdigate, Richard, first baronet (1602-1678)', DNB (Oxford University Press, 2004).

47 Petus is not recommended for this role by a favourite in any of the historical sources.

48 See Andrew Thrush, 'Fielding, William, first earl of Denbigh (c.1587-1643)', DNB (Oxford University Press, 2004). Another possible candidate for identification with Cesonius Petus is Sir Edward Cecil, later lord Wimbledon, who led the failed expedition to Cadiz in 1625. He was promoted by Buckingham despite reputedly being 'totally unused to sea, and an unsuccessful land commander ... in preference to abler men, in accordance with the whim of the favourite' (Fairholt, Poems and Songs, 26). Cecil was married to Lady Theodosia Cecil, a name similar to that of 
Theodora. See Roger Lockyer, 'Cecil, Edward, Viscount Wimbledon (1572-1638)', DNB (Oxford University Press, 2004).

49 Quoted in Lockyer, Buckingham, 437.

50 Ibid, 285. See also Stuart Handley, 'Villiers, John, Viscount Purbeck (1591?-1658)', DNB (Oxford University Press, 2004).

51 For references to documents relating to the case, see Mary Anne Everett Green (ed.), Calendar of State Papers of the Reign of James I, 1623-1625, Domestic Series (London, 1859; rpt Nendeln, 1967), 471, 474, 477, 478, 485, 497, 507.

52 Ibid, 485, 90, 241, 280.

53 See Alastair Bellany, 'The Murder of John Lambe: Crowd Violence, Court Scandal and Popular Politics in Early Seventeenth-Century England', Past and Present 200 (2008), 58. Bellany's article offers a fascinating account of contemporary views of Lambe's career and death.

54 See Anita McConnell, 'Lambe, John (1545/6-1628)', DNB (Oxford University Press, 2004).

55 Bellany, 'The Murder of John Lambe', 44.

56 Ibid, 64.

57 Ibid, 67.

58 See Holstun, Ehud's Dagger, 173-4.

59 In 1621 Jonson was granted a reversion to the master of the revels office after Sir John Astley. Astley later sold 'a life tenancy of the Mastership' to Sir Henry Herbert, making it unlikely that Jonson would succeed to the role. Janet Clare, Art made tongue-tied by authority': Elizabethan and Jacobean Dramatic Censorship, 2nd edn (Manchester, 1999), 209.

60 For a discussion of this entertainment, see, for example, Dale B.J. Randall, Jonson's Gypsies Unmasked: Background and Theme of The Gypsies Metamorphos'd (Durham, NC, 1975).

61 See Lockyer, Buckingham, 34-5.

62 Ibid, 155.

63 See ibid, 27, 28, 32, 155, 25, 28, 61.

64 Ibid, 38.

65 Cited in Rushworth, Historical Collections, 311.

66 Cited ibid, 343. Continental royal favourites like Cardinal Richelieu and the countduke of Olivares faced similar criticism for promoting relatives. See Linda Levy Peck, 'Monopolizing Favour: Structures of Power in the Early Seventeenth-Century English Court', J.H. Elliott and L.W.B. Brockliss (eds), The World of the Favourite (New Haven, 1999), 54. 
67 Theodora talks of feeling 'the foolish title of Lady / creeping vpon me by degrees' (2.1.657-8), and Hillarius later suggests that he is a newly elevated lord, explaining that he only dares speak 'big' 'among $y^{\mathrm{e}}$ yeomandrie of th' / Lords, \& specially those that ha' bene made since / I was' (5.1.3259; 3260-2).

68 Cited in Rushworth, Historical Collections, 392.

69 Norman Egbert McLure (ed.), The Letters of John Chamberlain, 2 (Philadelphia, 1939), 3 February 1621, 338.

70 Anthony Weldon, The Court and Character of King James (London, 1650), 134-5.

71 Buckingham's tactics were no more popular, and his alleged buying of offices formed part of the impeachment charges against him in 1626. See Rushworth, Historical Collections, 310-12.

72 Lockyer, Buckingham, 89.

73 Williamson, George Villiers, 96.

74 Lockyer, Buckingham, 90.

75 The countess of Buckingham is reported to have accepted a similar 'gift' (of $£ 2000$ ) from Sir John Egerton, after he received a patent through the duke of Buckingham's favour. Linda Levy Peck, Court Patronage and Corruption in Early Stuart England (London, 1999), 83. We also know that Buckingham delegated the handling of some petitioners to his kin. In 1620, John Chamberlain wrote that the 'Lord of Buckingham is so oppressed with multiplicitie of business, that he puts over a great part to his brother Purbecke, and (as I heare) referres all suitors to him' (1 January 1620). McClure, Letters, 279.

76 On the strength of contemporary suspicions about Buckingham and their relevance to views of events in Bohemia and the Palatinate, see, for example, Thomas Cogswell, The Blessed Revolution: English Politics and the Coming of War, 1621-24 (Cambridge, 1989), 52.

77 Cited in Rushworth, Historical Collections, 367.

78 The 1628 parliamentary remonstrance against Buckingham alluded to 'the miserable disasters, and ill successe that ... accompanied' these same missions, listing them as one of the 'euils and dangers' for which parliament held Buckingham responsible. See Rushworth, 636.

79 On the stereotypical association of court favourites with sexual transgression, and the use of 'sexual depravity as a metaphor for political corruption', see, for example, Pauline Croft, 'The Reputation of Robert Cecil: Libels, Political Opinion and Popular Awareness in the Early Seventeenth Century', Transactions of the Royal Historical Society, 6th ser, pt 1 (1991), 59; McRae, Literature, Satire and the Early Stuart State, 121; Perry, Literature and Favouritism, 2; and DiGangi, 'A Beast So Blurred', 158. 
80 One of the few stories about Buckingham that suggests an element of sexual coercion refers to his future wife, Katherine Manners (1603?-1649). It was claimed that on one occasion the countess of Buckingham persuaded Katherine to stay overnight at her house (where Buckingham was also staying). Katherine's father initially refused to accept his daughter when she attempted to return home because her reputation had been compromised. Buckingham, in turn, refused to marry her, although an agreement was later reached (Lockyer, Buckingham, 59-60). A similar episode is nearly contrived in the play. As part of Crispinus's scheme to secure a marriage between Aurelia and his brother, he attempts to persuade Aurelia to spend the night at his lodgings; she refuses on the grounds that her reputation would be damaged and that she would be spurned by her father (2.1.1059-63).

81 Perhaps surprisingly, there does not appear to be any overt suggestion of a homoerotic dimension to Crispinus's relationship with Nero, as was suspected between Buckingham and James I, possibly because the play's Nero is more closely modelled on Charles I.

82 Perry, Literature and Favouritism, 252-3.

83 Cited in Rushworth, Historical Collections, 358.

84 Johnson, Keeler, Cole, and Bidwell (eds), 4.130.

85 Cited in Rushworth, Historical Collections, 638.

86 Martin Butler suggests that many Caroline playwrights sought to use the strategies of 'analogy and oblique reflection' in this way. Butler, Theatre and Crisis, 6.

87 Cited in Perry, Literature and Favouritism, 229.

88 Charles was compared with Nero by other writers. See Bradford, 'Stuart Absolutism', 147. He was also likened to infamous English rulers such as Richard II, Edward II, and Richard III. Joad Raymond, 'Popular Representations of Charles I', Thomas N. Corns (ed.), The Royal Image: Representations of Charles I (Cambridge, 1999), 54.

89 See James Craigie (ed.), The Poems of James vi of Scotland, 2 vols (Edinburgh, 1958), 2.182, 116 and James I, The True Lawe of Free Monarchies (Edinburgh, 1598), no page numbers.

90 James I, no page numbers.

91 Glenn Burgess, Absolute Monarchy and the Stuart Constitution (New Haven, 1996), 209.

92 Ibid, 210.

93 Johnson, Keeler, Cole, Bidwell (eds), 3.140.

94 Butler, 'Romans in Britain', 154.

95 wCro, John Newdigate's 1628 Parliamentary Diary, CR136/A1, f 12v, f 51.

96 On this point, see Butler, 'Romans in Britain', 152. 
97 A 1920 sales catalogue of books from Arbury Hall lists an unbound 1629 copy of Massinger's play that could have been owned by Newdigate. See WCRO, NFP, CR136 M.I. 351/9, Item 52: 1920 Catalogue of Books for Sale.

98 See Albert H. Tricomi, Anticourt Drama in England, 1603-1642 (Charlottesville, 1989), 133-141.

99 The anonymous Tragedy of Nero (London, 1624), for example, is implicitly sympathetic in its presentation of the men who conspire to overthrow Nero. See Bradford, 'Stuart Absolutism', 144.

100 Blair Worden, 'Favourites on the English Stage', J.H. Elliott and L.W.B. Brockliss (eds), The World of the Favourite (New Haven, 1999), 166.

101 Lockyer, Buckingham, 466.

102 Rebecca Bushnell notes that we see 'little', likewise, of Tiberius's tyrannical actions, in Jonson's Sejanus. Tragedies of Tyrants: Political Thought and Theater in the English Renaissance (Ithaca, 1990), 132.

103 Lockyer, Buckingham, 466.

104 Cited in Rushworth, Historical Collections, 632, 637.

105 On 5 June 1628, as the House of Commons debated the wording of the remonstrance and the question of whether to name Buckingham directly, Mr Pyne observed that 'I think we can hardly tax the man in question without blaming a greater power'. Johnson, Keeler, Cole, and Bidwell (eds), Commons Debates, 4.131.

106 Cited in Rushworth, Historical Collections, 227.

107 Cited ibid, 360.

108 The issue of honours not being shared with those who were worthy formed part of the 1626 impeachment charges against Buckingham, and the topic of men being sent on foreign employments as a punishment was raised during the 1628 parliament. See Rushworth, Historical Collections, 310, and Johnson, Keeler, Cole and Bidwell (eds), Commons Debates 1628, 2.72.

109 Holstun, Ehud's Dagger, 190. George Eglisham, one-time physician of James I, famously accused Buckingham of poisoning James, and called for the duke to be put on trial for the alleged crime in The Forerunner of Revenge (Franckfort, 1626). The accusation of poisoning formed the final charge of the 1626 parliamentary impeachment of Buckingham. See Rushworth, Historical Collections, 354-6. Other favourites (such as Robert Dudley, earl of Leicester) were also accused of being poisoners. On the contemporary association of favourites with poisoning, see Perry, Literature and Favouritism, 97, and 99-100.

110 See, for example, Rushworth, Historical Collections, 310, 318, 344, and for Perrot's suggestion, see WCRO, John Newdigate's 1628 Parliamentary Diary, CR136/A3, f $20 \mathrm{v}$. 
111 Holstun, Ehud's Dagger, 171.

112 See Bellany and McRae, 'Early Stuart Libels', 803-4.

113 See ibid, 978-9, 1005-6.

114 On Charles's rule in this period, see, for example, Kevin Sharpe, The Personal Rule of Charles I (New Haven, 1995).

115 In this respect the play resembles Jonson's Sejanus which, as Malcolm Smuts notes, 'holds out no real promise of reform'. Malcolm Smuts, 'Court-Centred Politics and the Uses of Roman Historians, c.1590-1630', Kevin Sharpe and Peter Lake (eds), Culture and Politics in Early Stuart England (Basingstoke, 1994), 21-43.

116 Roger Lockyer (ed.), with an introduction by C.V. Wedgwood, The Trial of Charles I: A Contemporary Account Taken from the Memoirs of Sir Thomas Herbert and John Rushworth (London, 1959), 115, 112.

117 Bellany, “"Rayling Rymes and Vaunting Verse”, 304.

118 Howard-Hill, 'Another Warwickshire Playwright', 56.

119 See ibid, 56-7 for a discussion of the stage directions in the Arbury plays.

120 Dering appears to have staged several plays at his home in 1623-4, including John Fletcher's The Spanish Curate (London, 1622) and a conflated version of Shakespeare's Henry IV Parts I and II (London, 1598 and London, 1600, respectively). A surviving cast list for The Spanish Curate suggests that the parts were taken by a mixture of friends, family, and servants, including 'Jack of the Buttery'. See the introduction to William Shakespeare, George Walton Williams and Gwyne Blakemore Evans (eds), The History of King Henry the Fourth, as revised by Sir Edward Dering (Charlottesville, 1974), xi, viii. On Fane's staging of 'politicised entertainments', see, for example, Susan Wiseman, Drama and Politics in the English Civil War (Cambridge, 1998), 94.

121 M.J. Kidnie, 'Near Neighbours: Another Early Seventeenth-Century Manuscript Copy of The Humorous Magistrate', English Manuscript Studies, 1100-1700 (2007), 205-7.

122 The play includes twenty-two speaking parts, plus non-speaking extras, but with doubling The Emperor's Favourite could have been performed or read by a cast as small as fifteen, made up perhaps of family, friends, and other household members, as at Surrenden.

123 See The Emperor's Favourite, xxi-xxii for a discussion of the marginal markings that appear on the manuscript of the play.

124 For a modern edition of this version of the play, see Herbert G. Wright (ed.), Ghismonda. A Seventeenth-Century Tragedy (Manchester, 1944).

125 On Sir John Dolben, see Nigel Aston, 'Dolben, Sir John, second baronet (16841756)', DNB (Oxford University Press, 2004). 
126See National Archives, London, Prob/11/355, f 238v.

127 The Sheldon Papers in the Bodleian Library (Additional Ms C.302-3, 304a-b, 305-7), were purchased from Sir John Dolben's grandson, John English Dolben (1750-1837) in 1824; Gilbert Dolben's name appears on the inside front cover of one of the books of Sheldon's papers (see Bodl, Add. Ms C.308).

128 Edgar Osborne, who owned the manuscript prior to its purchase by the University of Calgary, claimed to have bought the play during a sale at Watnall Hall in 1947. See Kidnie, 208. Privately, Mary Polito suggests that the sale actually occurred in 1954, and it is not impossible that Osborne acquired the manuscript from Arbury Hall during his time as librarian there, from 1955 to 1967.

129 This phrase is borrowed from Holstun, Ehud's Dagger, 156.

130 Bellany, "Rayling Rymes and Vaunting Verse", 304.

131 See John Morrill's influential study of Cheshire-based gentleman William Davenport (1558-1655), whom Morrill describes as a "'pure” country gentleman', representative in his views of 'the "silent majority" of early Stuart England': 'William Davenport and the "Silent Majority" of Early Stuart England', Journal of the Chester Archaeological Society 58 (1975), 121, 127.

132 For a fascinating account of Holles's political poetry as well as his interest in writing and reading 'manuscript political libels', see Thomas Cogswell, “'The Symptomes and Vapors of a Diseased Time": The Earl of Clare and Early Stuart Manuscript Culture', Review of English Studies 57.203 (2006), 329.

133 Julie Sanders and Ian Atherton, 'Introducing the 1630s: Questions of Parliaments, Peace and Pressure Points', Ian Atherton and Julie Sanders (eds), The 1630s: Interdisciplinary Essays on Culture and Politics in the Early Caroline Era (Manchester, 2006), 9.

$134 \mathrm{On}$ the theatre's potential role in shaping 'political consciousness' in the period see Butler, Theatre and Crisis, 281. 


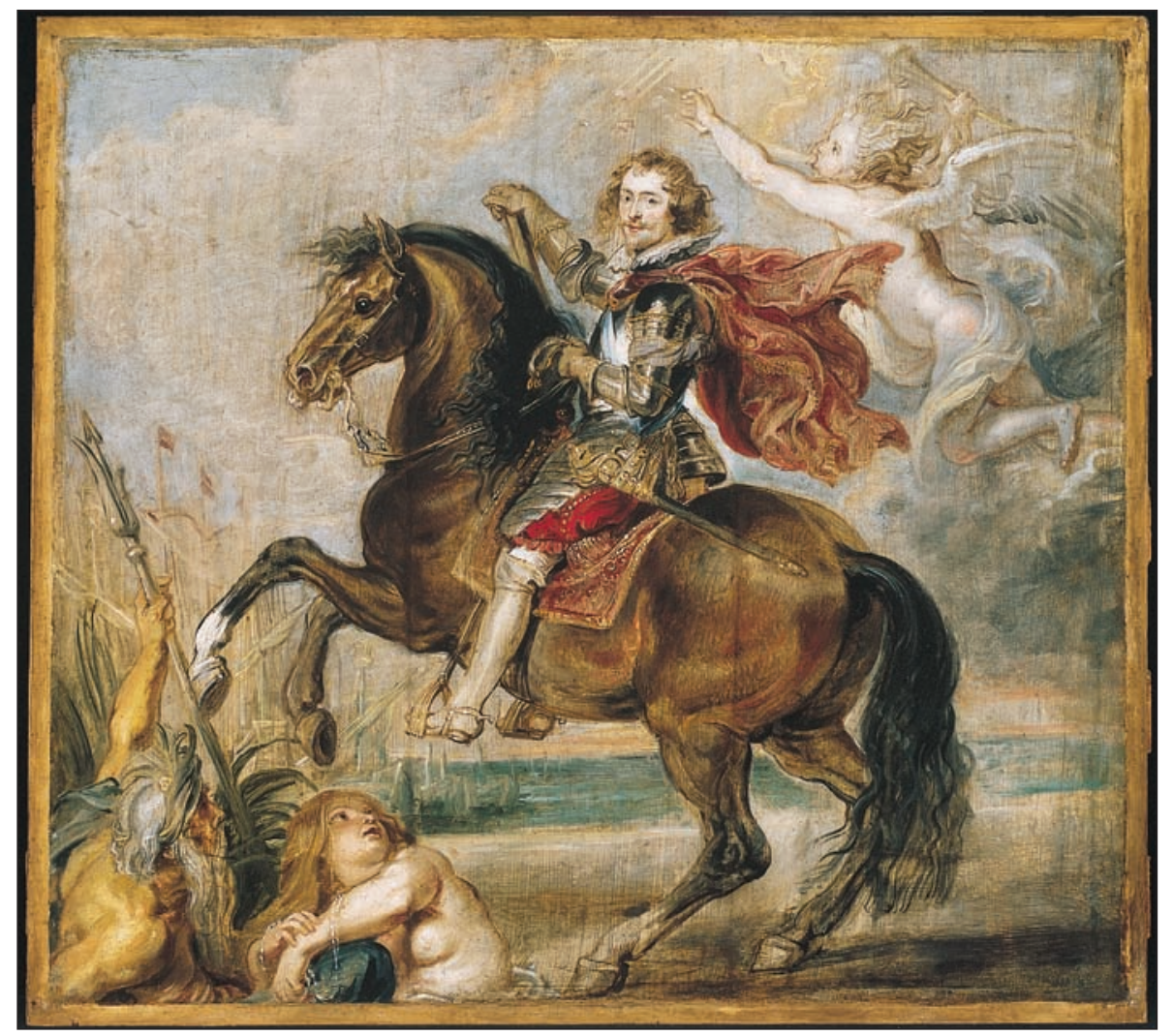

Plate 3. Equestrian Portrait of the [first] Duke of Buckingham [George Villiers], oil on panel by Peter Paul Rubens, 1625, Kimbell Art Museum, Fort Worth, Texas / Art Resource, NY. 